\title{
PENGARUH EARNING PER SHARE, STRUKTURAL MODAL DAN RETURN ON EQUITY TERHADAP HARGA SAHAM PADA PERUSAHAAN SEKTOR PERTAMBANGAN YANG TERDAFTAR DI BEI
}

\author{
${ }^{1}$ Michael Sinaga, ${ }^{2}$ Zufrizal Harahap, ${ }^{3}$ Sri Rahayu \\ ${ }^{1,2,3}$ Universitas Islam Sumatera Utara \\ ${ }^{1}$ michaelsinaga2612@gmail.com, ${ }^{2}$ zufrizal@fe.uisu.ac.id, ${ }^{3}$ sri.rahayu@fe.uisu.ac.id
}

\begin{abstract}
The stock price is the main factor that is considered by investors in making investment. The purpose of this study is to observe the relationship between earnings per share, capital structure and financial performance with stock prices. The type of research data that can be used is a quantitative approach. The sampling that can be used is the purposive sampling technique, and there are 19 companies in the mining sector that are sampled in 44 companies. The data source used is secondary data obtained from the Indonesia Stock Exchange, 2017 to 2019. The results of this study indicate that, individually, earnings per share have a positive and significant impact on stock prices and structural capital has a negative and significant impact on stock prices, while financial performance has no significant effect on stock prices.
\end{abstract}

Keywords : Earning Per Share, Structural Capital, Financial Performance, Stock Prices

ABSTRAK : Harga saham menjadi faktor utama yang diperhatikan oleh para investor dalam melakukan penanaman modal. Tujuan penelitian ini yaitu, mengamati keterkaitan antara earning per share, struktural modal dan kinerja keuangan dengan harga saham. Jenis data penelitian yang dapat dimanfaatkan yaitu pendekatan kuantitatif. Penarikan sampel yang dapat dimanfaatkan yaitu teknik purpossive sampling, dan terdapat 19 perusahaan pada sektor pertambangan yang menjadi sampel pada 44 perusahaan. Sumber data yang dipakai adalah data sekunder yang didapatkan dari Bursa Efek Indonesia, tahun 2017 sampai dengan 2019. Hasil penelitian ini menunjukkan bahwa, secara induvidual earning per share mempunyai positif serta signifikan dengan harga saham dan struktural modal mempunyai pengaruh negatif serta signifikan dengan harga saham, sedangkan kinerja keuangan tidak mempunyai pengaruh signifikan dengan harga saham.

Kata Kunci : Earning Per Share, Struktural Modal, Kinerja Keuangan, Harga Saham

\section{Pendahuluan}

\subsection{Latar Belakang Masalah}

Harga saham menjadi hal yang paling di amati oleh para investor dalam melaksanakan penanaman modal, karena dapat membuktikan prestasi pada emiten. Harga saham yang tercatat di pasar modal terbagi menjadi beberapa kategori, yaitu harga tertinggi dan terendah, serta harga penutupan. Harga tertinggi ataupun terendah, hanya dapat terjadi dalam sehari pada bursa efek. Permasalahannya yaitu kemampuan investor dalam menilai saham dan berbagai faktor yang mempengaruhi, seperti earning per share, struktural modal serta kinerja keuangan.

Salah satu aspek yang menarik minat para investor atas kondisi finansial pada perusahaan yaitu earning per share, yang merupakan pengukuran yang dapat membuktikan besarnya profit yang diterima dari saham yang beredar. Laba pada lembar saham mampu untuk menggambarkan keberhasilan pada emiten, sekaligus menjadi informasi bagi para investor yang paling mendasar dan juga berguna, karena juga mampu untuk memberikan gambaran mengenai kondisi finansial perusahaan di masa mendatang, serta dapat mempengaruhi kenaikan dan penurunan harga saham (Nurhayati, 2016).

Struktural modal juga merupakan suatu bahan pertimbangan bagi para investor, dalam melaksanakan penanaman modal pada perusahaan. Struktural modal dengan debt to 
equity ratio sebagai tolak ukurnya, membuktikan besarnya kemampuan emiten dalam melunasi hutangnya kepada pihak luar. Semakin banyak hutang yang didapatkan perusahaan, maka akan semakin besar suatu pinjaman yang harus dibayar, sehingga dapat mencerminkan resiko bisnis yang relatif besar (Topowijono, 2018).

Kinerja keuangan dengan return on equity sebagai tolak ukurnya, yaitu pengukuran profitabilitas dari sudut pandang para investor. Hal tersebut dikarenakan bahwa hasil pengembalian ini dapat memberikan suatu gambaran mengenai pengembalian yang diperoleh ataupun didapatkan perusahaan. Besarnya tingkat pengembalian yang didapatkan, akan dapat mempengaruhi peningkatan terhadap kondisi finansial perusahaan. Tinggi ataupun rendahnya hasil pengembalian yang diperoleh pada perusahaan, tentunya akan berkaitan langsung dengan naik dan turunnya harga saham.

\subsection{Rumusan Masalah}

Beikut ini adalah permasalahan pada penelitian ini, yaitu sebagai berikut :

a. Bagaimana pengaruh earning per share dengan harga saham?

b. Bagaimana pengaruh struktural modal dengan harga saham?

c. Bagaimana pengaruh kinerja keuangan dengan harga saham?

d. Bagaimana pengaruh earning per share, struktural modal dan kinerja keuangan dengan harga saham?

\section{Landasan Teori}

\subsection{Earning Per Share}

Earning per share adalah penilaian terhadap pengukuran yang dapat dimanfaatkan untuk melakukan perbandingan terhadap laba neto yang akan diberikan pada pemilik saham dengan jumlah saham perusahaan. Besarnya laba pada lembar saham pada perusahaan, dapat ditinjau dari informasi pelaporan keuangan, meskipun ada sebagian perusahaan yang tidak mencatat besarnya laba pada lembar saham perusahaan yang didapatkan, serta bersangkutan dengan hasil laporannya (Tandelilin, 2010).

\subsection{Struktural Modal}

Struktural modal merupakan pembelanjaan bersifat tetap yang mencerminkan suatu perbandingan antara hutang dengan ekuitas, dimana struktur modal ini sangat berbeda dengan kapitalisasi. Hal ini dikarenakan struktural modal merupakan susunan dari berbagai jenis modal yang membentuk kapitalisasi tersebut. Struktural modal masih termasuk dalam ruang lingkup keputusan pendanaan (Riyanto, 2011).

\subsection{Kinerja Keuangan}

Kinerja keuangan yaitu analisis yang dapat digunakan untuk mengamati kemampuan perusahaan yang melaksanakan kinerjanya dengan aturan - aturan pelaksanaan yang benar, atau juga dapat dikatakan sebagai pelaporan keuangan yang memenuhi beberapa peraturan dalam Standar Akuntansi Keuangan. Kinerja keuangan sangat berfungsi bagi berbagai pihak yang terdiri dari investor, manajemen serta berbagai pihak lainnya yang memiliki kepentingan (Fahmi, 2011).

\subsection{Harga Saham}

Harga saham yaitu satuan pada angka yang disepakati bersama. Harga saham dapat dibentuk sesuai dengan permintaan dan juga penawaran di bursa saham atau biasanya juga disebut sebagai harga penutupan (Sunariyah, 2011).

\subsection{Kerangka Konseptual}

Berdasarkan uraian pada latar belakang, rumusan masalah serta landasan teori di atas, maka kerangka konseptual dapat dijelaskan dalam bentuk gambar berikut ini : 


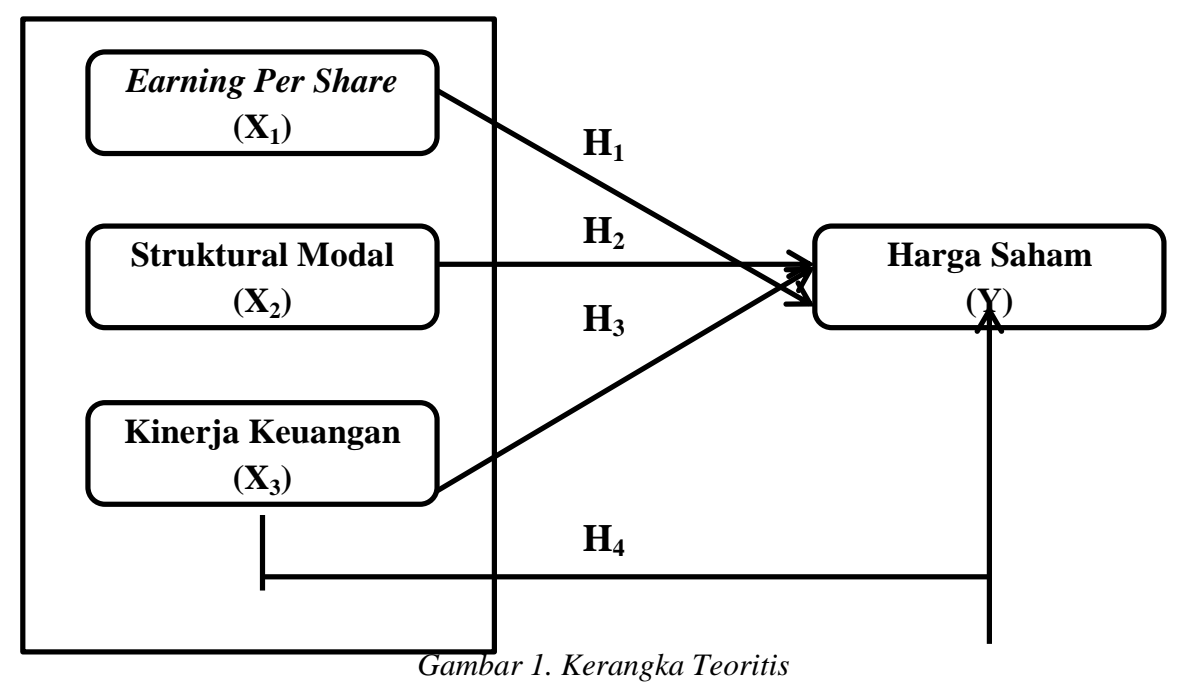

\subsection{Hipotesis}

Hipotesis yang digunakan pada penelitian ini, yaitu sebagai berikut :

$\mathrm{H}_{1} \quad$ : Earning Per Share berpengaruh signifikan dengan Harga Saham.

$\mathrm{H}_{2}$ : Struktural Modal berpengaruh signifikan dengan Harga Saham.

$\mathrm{H}_{3}$ : Kinerja Keuangan berpengaruh signifikan dengan Harga Saham.

$\mathrm{H}_{4}$ : Earning Per Share, Struktural Modal dan Kinerja Keuangan berpengaruh signfikan dengan Harga Saham.

\section{Metode Penelitian}

\subsection{Populasi Dan Sampel}

Populasinya yaitu berjumlah 44 perusahaan pertambangan yang tercatat di Bursa Efek Indonesia, tahun 2017 - 2019. Sedangkan jumlah sampelnya yaitu sebanyak 19 perusahaan pada sektor pertambangan. Penentuan pada sampel dapat dilakukan dengan cara memanfaatkan teknik purpossive sampling, yaitu suatu penentuan sampel berdasarkan pertimbangan ilmiah dan juga kriteria yang telah ditentukan.

\subsection{Sumber Data}

Sumber data yang dapat dimanfaatkan yaitu Data Sekunder, adalah suatu data yang didapatkan secara tidak langsung, seperti dokumen, artikel, literatur serta referensi yang berkaitan dengan objek penelitian, baik yang dipublikasikan ataupun tidak dipublikasikan.

\subsection{Definisi Operasional Variabel}

Definisi operasional variabel dapat membuktikan karakteristik objek ke dalam berbagai elemen yang telah di observasi, serta menyebabkan konsep yang dapat dioperasionalkan dalam bentuk penelitian. Variabel yang digunakan yaitu meliputi :

\section{a. Variabel Independen}

\begin{tabular}{lcl} 
Earning Per Share & $: \frac{\text { Laba Tahun Berjalan }}{\text { Jumlah Laba Saham Beredar }}$ \\
Struktural Modal & $:$ & $\frac{\text { Total Hutang (Debt) }}{\text { Ekuitas (Equity) }}$ \\
$\begin{array}{l}\text { Kinerja Keuangan } \\
\text { Ekuitas }\end{array}$ & $:$ Laba Tahun Berjalan \\
\hline
\end{tabular}

\section{b. Variabel Dependen}




\section{Harga Saham : Closing Price \\ 3.4. Teknik Pengumpulan Data}

Teknik pengumpulan data yang dimanfaatkan untuk mendapatkan informasi yang tepat pada penelitian ini, yaitu dokumentasi yang merupakan perolehan data yang dilakukan dengan mengumpulkan data berupa pelaporan keuangan yang diperiksa atau diaudit serta laporan harga saham yang bersumber pada Bursa Efek Indonesia.

\subsection{Teknik Analisis Data}

Teknik analisis data pada penelitian ini yaitu regresi linier berganda, yaitu analisa yang berfungsi untuk mengamati keterkaitan antara variabel independen atau variabel bebas dengan variabel dependen atau variabel terikat (Juliandi, 2014).

Regresi linier berganda pada penelitian ini memiliki tujuan untuk menguji hubungan antara variabel independen atau variabel bebas dengan variabel dependen atau variabel terikat. Persamaan pada regresi linier berganda, yaitu sebagai berikut :

$$
Y=\alpha+\beta 1 X 1+\beta 2 X 2+\beta 3 X 3+e
$$

\section{Hasil Penelitian \\ 4.1. Analisis Deskriptif}

Tabel 1. Statistik Deskriptif

Descriptive Statistics

\begin{tabular}{|l|r|r|r|r|r|}
\hline & N & Minimum & Maximum & Mean & \multicolumn{1}{c|}{$\begin{array}{c}\text { Std. } \\
\text { Deviation }\end{array}$} \\
\hline Earning Per Share & 57 &, 60 & 2268,63 & 228,4712 & 380,11954 \\
Struktural Modal & 57 &, 12 & 11,91 & 1,5040 & 2,00556 \\
Kinerja Keuangan & 57 &, 00 &, 85 &, 1872 &, 17530 \\
Harga Saham & 57 & 50 & 19875 & 2028,04 & 3723,689 \\
Valid N (listwise) & 57 & & & & \\
\hline
\end{tabular}

Sumber : Data SPSS, 2021

Berdasarkan analisis pada data output di atas, menjelaskan bahwa jumlah nilai $\mathrm{N}$ atau jumlah data yaitu sebanyak 57 data. Hasil tersebut diperoleh dari jumlah sampel yang telah diteliti yaitu sebesar 19 perusahaan, dengan jangka waktu penelitian dan observasi selama 3 tahun. Dari hasil pada data output di atas, maka juga diketahui bahwa :

a. Earning Per Share mempunyai nilai minimum dengan jumlah 0,60 , nilai maksimum dengan jumlah 2268,63 , nilai rata - rata dengan jumlah 228,4712 , dan standar deviasi dengan jumlah 380,11954.

b. Struktural Modal mempunyai nilai minimum dengan jumlah 0,12 , nilai maksimum dengan jumlah 11.91, nilai rata - rata dengan jumlah 1,5040, dan standar deviasi dengan jumlah 2,00556 .

c. Kinerja Keuangan mempunyai nilai minimum dengan jumlah 0,00 , nilai maksimum dengan jumlah 0,85 , nilai rata rata dengan jumlah 0,1872 , dan standar deviasi dengan jumlah 0,17530 .

d. Harga Saham mempunyai nilai minimum dengan jumlah 0,50 , nilai maksimum dengan jumlah 0,19876, nilai rata - rata dengan jumlah 2028,04, dan standar deviasi dengan jumlah 3723,689 .

\subsection{Uji Parsial}

Tabel 2. Hasil Uji Parsial (Uji t)

Coefficients $^{\mathrm{a}}$

\begin{tabular}{|l|r|r|r|r|r|}
\hline \multirow{2}{*}{ Model } & \multicolumn{2}{|c|}{$\begin{array}{c}\text { Unstandardized } \\
\text { Coefficients }\end{array}$} & \multicolumn{1}{c|}{$\begin{array}{c}\text { Standardized } \\
\text { Coefficients }\end{array}$} & \multicolumn{1}{c|}{ Sig. } \\
\cline { 2 - 4 } & \multicolumn{1}{|c|}{ B } & \multicolumn{1}{c|}{ Std. Error } & \multicolumn{1}{c|}{ Beta } & & \\
\hline \multirow{2}{*}{ (Constant) } & 6,435 &, 183 & & 35,154 &, 000 \\
Earning Per Share &, 002 &, 000 &, 522 & 4,397 &, 000 \\
Etruktural Modal &,- 247 &, 072 &,- 372 & $-3,450$ &, 001 \\
Kinerja Keuangan & 1,419 &, 939 &, 186 & 1,511 &, 137 \\
\hline
\end{tabular}

a. Dependent Variable: Harga Saham 
Sumber : Data SPSS, 2021

Pada hasil analisis dari data output di atas, maka peneliti akan menarik kesimpulan dengan melakukan perbandingan antara nilai signifikansi (Sig.) dengan tingkat signifikansi yaitu sebesar $0,05(\alpha=5 \%)$, dan juga nilai $t_{\text {hitung }}$ dengan $t_{\text {tabel }}$ yaitu sebesar 2,005. Pada berbagai perbandingan yang dilakukan, maka dapat ditarik kesimpulan terhadap penelitian ini, yaitu sebagai berikut :

a. Earning Per Share mempunyai nilai signifikansi yang berjumlah $0,000<0,05$ dan nilai $t_{\text {hitung }}$ yang berjumlah 4,397> 2,005. Maka dikatakan bahwa Earning Per
Share berpengaruh dengan nilai yang positif dengan Harga Saham.

b. Struktural Modal mempunyai nilai signifikansi yang berjumlah 0,001 $<0,05$ dan nilai $t_{\text {hitung }}$ yang berjumlah $-3,450>$ 2,005. Maka dikatakan bahwa Struktural Modal memiliki berpengaruh dengan nilai yang negatif dengan Harga Saham.

c. Kinerja Keuangan mempunyai nilai signifikansi yang berjumlah 0,137>0,05

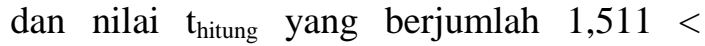
2,005. Maka dikatakan bahwa Kinerja Keuangan tidak berpengaruh dengan Harga Saham.

\subsection{Uji Simultan}

Tabel 3. Hasil Uji Simultan (Uji F)

ANOVA $^{\mathrm{a}}$

\begin{tabular}{|c|c|c|c|c|c|}
\hline Model & $\begin{array}{l}\text { Sum of } \\
\text { Squares }\end{array}$ & $\mathrm{df}$ & Mean Square & $\mathrm{F}$ & Sig. \\
\hline $\begin{array}{l}\text { Regression } \\
\text { Residual } \\
\text { Total }\end{array}$ & $\begin{array}{l}58,044 \\
41,835 \\
99,880\end{array}$ & $\begin{array}{r}3 \\
53 \\
56\end{array}$ & $\begin{array}{r}19,348 \\
, 789\end{array}$ & 24,511 &, $000^{\mathrm{b}}$ \\
\hline
\end{tabular}

b. Predictors: (Constant), Kinerja Keuangan, Struktur Modal, Earning Per Share

Berdasarkan analisis pada data output di atas, maka peneliti akan menarik kesimpulan dengan melakukan perbandingan antara nilai signifikansi (Sig.) dengan tingkat signifikansi yaitu sebesar $0,05(\alpha=5 \%)$, dan juga nilai $\mathrm{f}_{\text {hitung }}$ dengan $\mathrm{f}_{\text {tabel }}$ yaitu sebesar 2,78. Dari berbagai perbandingan yang telah ditentukan, maka dapat disebutkan bahwa keseluruhan variabel independen meliputi Earning Per Share, Struktural Modal dan Kinerja Keuangan mempunyai nilai signifikansi yang berjumlah $0,000<0,05$ dan nilai $\mathrm{f}_{\text {hitung }}$ yang berjumlah $24,511>2,78$. Maka dikatakan bahwa Earning Per Share, Struktural Modal dan Kinerja Keuangan berpengaruh dengan nilai yang positif dengan Harga Saham.

\subsection{Uji Determinasi}

Tabel 4. Hasil Uji Determinasi $\left(\mathrm{R}^{2}\right)$ Model Summary ${ }^{\mathrm{b}}$

\begin{tabular}{|c|c|c|c|c|}
\hline Model & $\mathrm{R}$ & R Square & $\begin{array}{c}\text { Adjusted R } \\
\text { Square }\end{array}$ & $\begin{array}{l}\text { Std. Error of } \\
\text { the Estimate }\end{array}$ \\
\hline 1 &, $762^{\mathrm{a}}$ & ,581 & ,557 & ,88845 \\
\hline
\end{tabular}

Dari hasil pengujian pada data output di atas, maka disebutkan bahwa pada koefisien determinasi atau $R$ Square dengan jumlah 0,581 , yang kemudian dihitung dalam satuan persen (\%), yaitu sebagai berikut :

$$
\text { KD : } 0,581 \times 100 \%=58,1 \%
$$

Dari hasil perhitungan tersebut, maka besarnya nilai pada koefisien determinasi sama dengan 58,1\%. Maka dapat disebutkan bahwa kemampuan variabel independen yang meliputi Earning Per Share, Struktural Modal dan Kinerja Keuangan dalam menerangkan variasi pada variabel dependen yaitu dengan jumlah $58,1 \%$, sedangkan sisanya yaitu $41,9 \%$ 
dikaitkan oleh variabel lainnya diluar penelitian.

\section{Evaluasi Data}

\subsection{Pengaruh Earning Per Share Terhadap Harga Saham}

Hasil ini membuktikan bahwa earning per share mempunyai berpengaruh dengan nilai yang positif dengan harga saham. Hal tersebut mengindikasikan bahwa hasil laba pada lembar saham yang tinggi, mampu untuk meningkatkan nilai perusahaan, serta menjadi sinyal positif bagi investor untuk menanamkan modalnya dalam bentuk saham, dan berdampak langsung terhadap harga saham. Hasil ini sesuai dengan penelitian Sutapa (2018) yang menyimpulkan bahwa earning per share berpengaruh dengan nilai yang positif dengan harga saham.

Hasil laba per lembar saham yang tinggi, mengindikasikan bahwa suatu perusahaan dapat memberikan peluang terhadap penghasilan yang cukup tinggi bagi para investor, yang ingin menanamkan modalnya pada perusahaan. Oleh sebab itu, analisis terhadap laba pada lembar saham, sangat diperhatikan oleh investor, karena mendeskripsikan suatu gambaran mengenai profit yang akan didapatkan oleh pemegang saham, karena kesediannya dalam menginvestasikan dananya, sehingga dapat meningkatkan harga saham.

\subsection{Pengaruh Struktural Modal Terhadap Harga Saham}

Hasil ini membuktikan bahwa struktural modal berpengaruh dengan nilai yang negatif dengan harga saham. Artinya semakin besar hutang pada perusahaan, maka harga saham juga akan semakin berkurang. Hasil ini sejalan dengan penelitian Tika (2012) yang mengatakan bahwa struktural modal mempunyai pengaruh negatif serta signifikan dengan harga saham. Dan juga bertolak belakang dengan hasil penelitian Ircham (2014) yang mengatakan bahwa struktural modal mempunyai pengaruh positif serta signifikan dengan harga saham.

Hal ini mengindikasikan bahwa, nilai hutang atau modal pinjaman yang lebih besar daripada ekuitas atau modal perusahaan. Hal tersebut juga mempengaruhi keputusan investor agar tidak menginvestasikan modalnya, karena hutang yang tinggi akan dapat menimbulkan beban tetap yang tinggi dan berakibat fatal terhadap likuiditas perusahaan.

\subsection{Pengaruh Kinerja Keuangan Terhadap Harga Saham}

Hasil ini memberikan bukti bahwa kinerja keuangan tidak berpengaruh dengan harga saham. Hal tersebut dapat mengindikasikan bahwa besar dan kecilnya hasil pengembalian yang akan diperoleh, tidak akan memiliki dampak secara langsung terhadap kenaikan dan penurunan harga saham, sehingga para investor cenderung kurang dalam mengamati rasio ini untuk berinvestasi. Hasil ini sejalan dengan penelitian yang dikemukakan oleh Topowijono (2018) yang menyimpulkan bahwa kinerja keuangan tidak berpengaruh signifikan dengan harga saham.

Teori Fahmi (2011) menyebutkan bahwa kinerja keuangan yaitu analisa yang dilakukan untuk mengamati kemampuan perusahaan dalam melaksanakan aturan keuangan dengan benar, serta sesuai dengan ketetapan SAK (Standar Akuntansi Keuangan). Semakin besar kinerja keuangan pada perusahaan, maka posisi pemilik perusahaan juga semakin kuat. Dalam hal ini, dapat diartikan bahwa kinerja keuangan tidak berdampak secara langsung dengan harga saham. Hal ini disebabkan bahwa, return on equity bukanlah satu satunya indikator kinerja keuangan perusahaan, dalam menentukan keputusan terhadap harga saham. Selain itu, pembiayaan terhadap modal juga saling berkaitan dengan tingkat suku bunga pada suatu perusahaan.

\section{Kesimpulan}

Penelitian ini mempunyai tujuan untuk mengamati keterkaitan earning per share, struktural modal dan kinerja keuangan dengan harga saham secara induvidual maupun bersamaan, pada perusahaan pertambangan yang tercatat di Bursa Efek Indonesia (BEI) tahun 2017 sampai dengan 2019. Berdasarkan hasil pengolahan terhadap data yang telah dilaksanakan, maka dapat ditentukan kesimpulan berikut ini :

a. Earning Per Share secara induvidual berpengaruh dengan nilai yang positif dengan Harga Saham.

b. Struktural Modal secara induvidual berpengaruh dengan nilai yang negatif dengan Harga Saham.

c. Kinerja Keuangan secara induvidual tidak berpengaruh dengan Harga Saham.

d. Earning Per Share, Struktural Modal dan Kinerja Keuangan secara bersamaan 
berpengaruh dengan nilai yang positif dengan Harga Saham.

\section{DAFTAR PUSTAKA}

Fahmi, Irham. (2018). Pengantar Manajemen Keuangan (Cetakan Keenam). Bandung : Alfabeta.

Juliandi, A \& dkk. (2014). Metodologi Penelitian Bisnis (Cetakan Pertama). Medan : UMSU Press.

Nurhayati, Immas. (2016). Pengaruh Earning Per Share Terhadap Harga Saham (Studi Kasus Pada PT. Charoen Pokphan Indonesia). Jurnal Ilmiah Inovator : UIKA Bogor.

Riyanto, Bambang. (2011). Dasar - Dasar Pembelanjaan Perusahaan. Yogyakarta : BPFE UGM.

Sunariyah. (2011). Pengantar Pengetahuan Pasar Modal. Yogyakarta : Unit Penerbit \& Percetakkan.

Tandelilin, Eduardus. (2010). Portofolio Dan Investasi : Teori Dan Aplikasi. Yogyakarta : Kanisius.

Topowijono, D, H. (2018). Pengaruh Kinerja Keungan Terhadap Harga Saham (Studi Pada Perusahaan Pertambangan Subsektor Pertambangan Minyak Dan Gas Bumi Yang Terdaftar Di Bursa Efek Indonesia Periode 2013 - 2016). Jurnal Administrasi Bisnis : Universitas Brawijaya, Malang. 